Article

\title{
Oxygen Isotope Thermometry of DaG 476 and SaU 008 Martian Meteorites: Implications for Their Origin
}

\author{
Arshad Ali ${ }^{1,2, *}$, Iffat Jabeen ${ }^{2}$, Sobhi J. Nasir ${ }^{1}$ and Neil R. Banerjee ${ }^{2}$ \\ 1 Earth Sciences Research Centre (ESRC), Sultan Qaboos University (SQU), Al-Khodh, Muscat 123, Oman; \\ sobhi@squ.edu.om \\ 2 Department of Earth Sciences, Western University, 1151 Richmond Street N., London, ON N6A 5B7, Canada; \\ ijabeen67@gmail.com (I.J.); neil.banerjee@uwo.ca (N.R.B.) \\ * Correspondence: arshadali@squ.edu.om; Tel.: +968-9989-6917
}

Received: 2 July 2017; Accepted: 4 January 2018; Published: 8 January 2018

\begin{abstract}
We report the equilibration temperatures derived from the oxygen isotope thermometry of pyroxene-olivine pair from the Dar al Ghani (DaG) $476\left(1200+105 /-90^{\circ} \mathrm{C}\right)$ and Sayh al Uhaymir (SaU) $008\left(1430+220 /-155^{\circ} \mathrm{C}\right)$ meteorites showing a difference of over $200{ }^{\circ} \mathrm{C}$ at the face values. Regardless of the large associated uncertainties, contrasting geochemical and isotopic characteristics such as oxygen fugacities, hydrogen isotopic compositions (referred to as the D/H ratios), olivine abundances, presence of merrillite and/or apatite, and their chlorine contents between the two meteorites are observed in the literature. These opposing features lend support to the idea that the relative difference observed in the estimated temperatures is probably real and significant, thus providing insights into the Martian mantle magmatism. Based on our temperature estimation and previous magmatic models, we propose that $\mathrm{SaU} 008$ could have been originated from a deeper depleted mantle source. However, DaG 476 may have been produced by the partial melting of the entrained pockets of the depleted mantle similar to that of the SaU 008's source at a relatively shallower depth. Both meteorites erupted as a relatively thick lava flow or a shallow intrusion at approximately the same time followed by a launch initiated by a single meteoritic impact 1.1 million years (Ma) ago.
\end{abstract}

Keywords: oxygen isotopes; thermometry; Martian magmatism; DaG 476; SaU 008

\section{Introduction}

The SNC (Shergotty-Nakhla-Chassigny) meteorites are the main source of information about the interior of Mars. They represent rocks from Martian volcanoes and magmatic intrusions into the crust of Mars [1-4]. These mafic to ultramafic rocks provide unique samples that can be used to decipher and understand the magmatic processes and the crystallization history of Mars [5,6]. Based on the crystallization ages of SNCs (150-4500 Ma) obtained from various geochronometers such as Sm-Nd, $\mathrm{Rb}-\mathrm{Sr}, \mathrm{Pb}-\mathrm{Pb}$, and $\mathrm{Ar}-\mathrm{Ar}$ [7-17], it appears that the Martian magmatism extended over most of the solar system history that agrees well with the time span of crater retention ages [18]. It is believed that shergottites-the most abundant of the Martian meteorites found to date-have been generated by the partial melting of the Martian mantle [8,19]; therefore, their geochemical signatures can provide insights into the Martian mantle chemistry. Furthermore, the depleted shergottites-for example, having low chondrite-normalized La/Y $(\sim 0.1)$, low initial ${ }^{87} \mathrm{Sr} /{ }^{86} \mathrm{Sr}(\sim 0.7013)$, low magmatic oxygen fugacity (i.e., quartz-fayalite-magnetite, QFM -3.5), and large positive $\varepsilon^{143} \mathrm{Nd}$ values $[5,7,8,20,21]$ —originated from a depleted mantle source region that has not seen significant alteration or melting since planetary differentiation at $4504 \pm 6 \mathrm{Ma}[9,17]$. Compared to the nakhlites and chassignites, shergottites, with the exception of Northwest Africa (NWA) 7635 (2405 Ma) [17], represent more than three-quarters of the known Martian meteorites (i.e., SNCs) with relatively young crystallization ages (150-574 Ma) [7,13,22]. However, according to several independent measurements made by the spacecraft, shergottite-like 
rocks are found in older terrains [23]. The depleted shergottites are relatively older than the intermediate and enriched types that include Yamato 980459 (Y980459), Dar al Gani (DaG) 476, Sayh al Uhaymir (SaU) 005/008, Dhofar 019, and NWA 7635. Most of the depleted shergottites were launched from the Mars surface by a single impact [17]. These meteorites are related via identical ejection ages (i.e., mean ejection age $=1.1 \pm 0.2 \mathrm{Ma} ; \mathrm{N}=11$ ) and compositionally identical mantle source [17]. There is no physical evidence that could suggest that these rocks are derived from the same terrain on Mars [15]. However, the majority of the depleted shergottites share similar ejection ages (1.1 $\pm 0.2 \mathrm{Ma}$; [17], except NWA 5990, NWA 7032, QUE 94201 (3 Ma) and Dhofar 019 (18 Ma), suggesting that most of them might have launched in a single impact probably from a similar terrain. Scientific community is working on possible craters on Mars to find out potential candidate locations where SNCs could have originated on the red planet and so far, several such craters have been found carrying characteristics identical to SNCs. Recently, it is found that young volcanic sequences (i.e., Tharsis plateau) on Mars may possibly be the source of shergottites [24,25]. Large-scale impacts on Martian surface have produced mechanical deformation ([26-29] and refs. therein) of major rock-forming minerals (i.e., px-ol), transformation of plagioclase to maskelynite ([30] and refs. therein), and formation of melt pockets, veins, and bubbles in the glass [31,32]. Shock features in olivine and pyroxene include planar deformation features, twinning, and mosaicism and these are abundant in both DaG 476 and SaU 005 [33]. On the other hand, shock effects in plagioclase are commonly observed in Martian and Lunar meteorites of basaltic origin [34,35]. Plagioclase can resist complete loss of crystallinity (i.e., changing to glass) up to $\sim 45 \mathrm{GPa}$ [36]. Furthermore, solid-state transformation of plagioclase to maskelynite needs not necessarily reset isotope systems [30].

In order to understand the magma generation in the Martian interior and its eruption mechanism, several models based on numerical and geochemical data were proposed [15,22,37-39]. Geochemical models regarding the source regions of the shergottites suggest that these regions have formed either as a result of solidification of a Martian magma ocean $[7,8,40,41]$ or by the interaction between mantle and crustal reservoirs [20,42].

The volatile budget in Martian magmas is also important to understand the eruption history on Mars [37] and the chemistry of the SNCs [43-46]. Water content can constrain the extent of oxidation [47] that may possibly affect the oxygen isotope compositions of the mantle minerals through isotopic exchange. Martian meteorites have shown the presence of water within Mars' interior [48-55]. However, Martian magmas may have suffered a partial loss of the volatiles by degassing upon eruption [56]. To counter this uncertainty, several studies have been carried out to estimate the pre-eruptive water contents of Martian magmas on the basis of $\mathrm{H}$-isotopes $[53,54,57]$. Furthermore, an experimental study [58] has suggested that at least $2 \mathrm{wt}$. \% of water is required to reproduce shergottite-like mineralogy and their possible temperatures of crystallization.

Over the last several decades, oxygen isotope compositions in coexisting rock-forming minerals have been used as a robust thermometric tool [59] and for confirming the isotopic equilibrium. For example, pyroxene-olivine pair is particularly important to interpret the oxygen isotope data of mantle samples and was successfully applied to Lunar basalts to estimate their crystallization temperatures [60-62]. However, terrestrial basalts show higher uncertainty in temperatures based on pyroxene-olivine thermometry due to their crystallization at higher temperatures leading to small isotopic fractionation. A part of oxygen isotope data of minerals in SNCs are compiled in our previous study (see Table 2 in [63]). Application of these data to estimate temperatures in SNCs is limited; for example, oxygen isotope compositions of various mineral pairs in Shergotty were utilized for this purpose [64]. To our knowledge, there is no other reporting of oxygen isotope thermometry on SNCs. Olivine-phyric shergottites [65] are the most promising primitive meteorites given their relatively high bulk-rock Mg\# values [= $100 \times$ molar $\mathrm{Mg} /(\mathrm{Mg}+\mathrm{Fe})]$. Our previous work was mainly dealing with the oxygen isotope compositions of bulk materials and mineral separates from SNCs [63]. The data were used to discuss the homogeneity of Martian mantle as a whole because we included samples from all representative members of the SNCs, thus representing different mantle sources. 
However, this contribution deals with a subset of oxygen isotope data of two meteorites (DaG 476 and $\mathrm{SaU}$ 008) from our previous paper [63] that mainly focuses on the oxygen isotope thermometry based on major-rock forming minerals (i.e., px-ol). It is fortuitous to have data of mineral fractions of these Martian meteorites from our previous work [63] because they are commonly studied depleted shergottites (olivine-phyric) having several characteristics in common (as mentioned above), such as being highly shocked, having identical ejection ages, relatively similar crystallization ages, and hot desert finds. The objective of the present study is to apply oxygen isotope thermometry to the olivine-phyric shergottites given their parent melt compositions closest to equilibrium with the Martian mantle. We used oxygen isotope compositions of the pyroxene-olivine mineral pair to estimate the equilibration temperatures of $\mathrm{DaG} 476$ and $\mathrm{SaU}$ 005/008 to investigate their igneous petrogenesis to better understand the Martian mantle and generation of shergottite magmas.

\section{Methodology}

\subsection{Samples}

Shergottites are commonly divided into basaltic, olivine-phyric, and lherzolitic groups based on their mineralogy [65]. SaU 008 was found in close proximity of the SaU 005 find location on the same day (i.e., 26 November 1999) from the deserts of Oman and they are recognized as paired along with several other meteorites [66]. Furthermore, SaU 008 shows a porphyritic texture with large olivine phenocrysts in a fine-grained groundmass of pigeonite and shocked-plagioclase, that is, maskelynite. On the other hand, DaG 476 is the first Martian meteorite found from hot desert in Dar al Gani, Sahara Desert, Libya (1 May 1998), having porphyritic texture; it is composed of olivine megacrysts in a fine-grained groundmass of pigeonite and maskelynite. Average olivine and pyroxene modal abundances are, respectively, $17.2 \mathrm{vol} \%$ and $58.5 \mathrm{vol} \%$ (i.e., ranging from 10.4 to $24 \mathrm{vol} \%$ and 54 to $64.6 \mathrm{vol} \%$, respectively) $[33,67,68]$. Both SaU 008 and DaG 476 meteorites are grouped as olivine-phyric shergottites given their highly depleted light rare earth elements (LREE) abundances.

Both DaG 476, SaU 005 and their pairings are similar in their texture, mineralogy, chemistry and exposure age [69]. However, the former is extensively weathered in terrestrial conditions [70] compared to the latter possibly due to their different residence periods on earth (i.e., DaG $476=85 \mathrm{ka}$, SaU $005=13 \mathrm{ka}$; [71]). Additionally, significant weathering for DaG 476 may also led to higher chlorine content (840 ppm; [33]) and K/La ratio (2630-4610; [7]) compared to those of SaU 005 $(\mathrm{Cl}=143 \mathrm{ppm}$; [72], K/La = 1465-1770; [8]). Furthermore, olivine in DaG 476 and its pairings contains Sr (e.g., 47-87 ppm) [73] and Ba (e.g., 36-84 ppm) [33,73] concentrations that are higher by a factor of 10-100 and 6-10, respectively, compared to those in their counterpart shergottites found in Antarctica [74]. The elevated Sr and Ba contents are due to terrestrial weathering resulting in the formation of secondary sulfate and carbonate [72,74].

\subsection{Oxygen Isotope Measurements}

Precise triple oxygen isotope measurements have recently been done on a suite of SNC meteorites including DaG 476 and SaU 008 by adopting a laser-assisted fluorination mass spectrometry at Laboratory for Stable Isotope Science (LSIS), Western University, Canada [63]. The distinctively colored minerals (i.e., pyroxene relatively darker than the lighter olivine) were separated by handpicking from a crushed specimen of the bulk meteorite under the optical microscopy. The separated fractions of pyroxene and olivine minerals were treated with $6 \mathrm{M} \mathrm{HCl}$ at $70{ }^{\circ} \mathrm{C}$ for $2-3 \mathrm{~min}$ in order to remove any terrestrial weathering products to make sure that our data represent actual isotope values for the minerals. Pre-dried samples (1-2 mg) were loaded as grains on the sample holder and placed in the sample chamber. After complete evacuation of the vacuum line, a reaction was performed by heating the sample with a $25 \mathrm{~W} \mathrm{CO}_{2}$ laser $(10.6 \mu \mathrm{m}$ wavelength; Merchantek, Bozeman, MT, USA; Model MIR10-25) in a $\mathrm{BrF}_{5}$ atmosphere to extract oxygen gas. Later, oxygen gas was purified using cryogenic metal traps and a heated $\mathrm{KCl}$ salt trap, giving yields of better than $95 \%$. The triple oxygen 
isotope ratios were determined using a Delta V Plus mass spectrometer in a dual inlet mode integrated with Isodat3.0 software for system controls and data acquisition. Data were reported as delta notation ( $\delta$ ) with respect to the Vienna Standard Mean Ocean Water (VSMOW; [75]). Details of the analytical procedures are reported elsewhere [63].

\section{Results and Discussion}

\subsection{Oxygen Isotope Thermometry}

Oxygen isotope thermometry is based on two fundamental assumptions: (i) isotopic equilibrium is maintained; (ii) and the exchange occurs by diffusion in a closed system [76]. Mineral data of both meteorites fall on a Martian fractionation line (i.e., MFL; [63]) with a slope of $0.532 \pm 0.009$ (SE) (Figure 1) which shows an isotopic equilibrium has been achieved and thereby satisfying the first assumption. On the other hand, for second assumption the fast grain boundary (FGB) diffusion model $[77,78]$ provides a flexible way to deal with stable isotope diffusion which suggests that the mass balance and diffusion for any number of minerals in a rock are linked. This is in contrast to the Dodson model, which proposes diffusion between a single mineral and an infinite reservoir [79]. Although no distinct closure temperature for any mineral is assumed in the FGB model, calculations are made during a transition towards a progressively slower diffusion during which a mineral ultimately no longer achieves measurable exchange and is effectively closed [76].

Oxygen isotope fractionation among common rock-forming minerals such as olivine and pyroxene (i.e., cpx), can be calculated by using a polynomial expression for individual minerals for all temperatures above $400 \mathrm{~K}$ (i.e., $127{ }^{\circ} \mathrm{C}$ ) [80]. Three oxygen isotope plot of the pyroxene-olivine pair in both shergottites, along with their respective bulk composition, shows that the minerals are in isotopic equilibrium (i.e., slope $=0.532 \pm 0.009$ (SE); Figure 1), as reported earlier [63] for the Martian fractionation line that is based on mineral separates. Furthermore, lower $\delta^{18} \mathrm{O}$ values in olivine compared to that of pyroxene (Table 1) are also indicative of the fact that the isotopic equilibrium has been achieved between the mineral pair [80]. The expressions for the oxygen isotope fractionation of diopside and forsterite minerals are shown in Equations (1) and (2), respectively [80]. We calculated the $f_{D i}$ and $f_{F o}$ values at temperatures between $600^{\circ} \mathrm{C}$ and $1700^{\circ} \mathrm{C}$ with a stepwise increment of 100 degrees. We selected higher temperatures for our calculations given the fact that oxygen isotope fractionation between these minerals have been studied experimentally at $600-1300{ }^{\circ} \mathrm{C}$ [81], and extrapolated to the typical temperature range of mantle melting zone (i.e., $1400-1700{ }^{\circ} \mathrm{C}$; [82]). The squared and cubed terms in the expressions (Equations (1) and (2)) are found to be negligibly low and has been ignored to get a simplified expression (Equation (3)). By plotting $10^{6} T^{-2}$ against $\Delta_{D i \text {-Fo }}$, we get a straight line (Equation (4)) with a slope of 0.8298 and intercept of 0.0233 (Figure 2). The parameters of the regression line (i.e., slope and intercept; Figure 2) are used to calculate temperatures (Equation (5)) for the mineral pair (pyroxene-olivine) from DaG 476 and SaU 008 meteorites assuming that their oxygen isotope fractionation during fractional crystallization are identical to that of the diopside and forsterite, respectively [83]. Temperatures of the mineral pair, calculated using the isotope fractionation relation given in Equation (6) derived from 1000ln $\alpha=A \times 10^{6} T^{-2}$ [81], show an excellent agreement.

$$
\begin{aligned}
& f_{D i}=9.237 \times\left(\frac{10^{6}}{T^{2}}\right)-0.199 \times\left(\frac{10^{6}}{T^{2}}\right)^{2}+0.0053 \times\left(\frac{10^{6}}{T^{2}}\right)^{3} \\
& f_{F o}=8.326 \times\left(\frac{10^{6}}{T^{2}}\right)-0.142 \times\left(\frac{10^{6}}{T^{2}}\right)^{2}+0.0032 \times\left(\frac{10^{6}}{T^{2}}\right)^{3}
\end{aligned}
$$


where

$$
\begin{gathered}
\Delta_{D i-F o}=f_{D i}-f_{F o} \\
\Delta_{D i-F o} \text { vs. }\left(\frac{10^{6}}{T^{2}}\right) \\
\Delta_{D i-F o}=0.8298 \times\left(\frac{10^{6}}{T^{2}}\right)+0.0233
\end{gathered}
$$

Rearranging Equation (4),

$$
\begin{gathered}
\left(\frac{10^{6}}{T^{2}}\right)=\frac{\left(\Delta_{D i-F o}-0.0233\right)}{0.8298} \\
T(K)=\sqrt{\frac{0.8298 \times 10^{6}}{\left(\Delta_{D i-F o}-0.0233\right)}} \\
T(K)=\sqrt{\frac{A \times 10^{6}}{1000 \ln \alpha}}
\end{gathered}
$$

where $\alpha$ and $A$ represent the fractionation between the minerals and the coefficient factor, respectively. For diopside-forsterite pair, $A=0.92 \pm 0.11$ [81]. A comparison has been made between the temperatures estimated for both meteorites using Equations (5) and (6) (Figure 3). Errors associated

\begin{tabular}{|c|c|c|c|c|c|c|c|c|c|}
\hline Sample & Mineral & $\delta^{18} \mathrm{O}(\% \mathrm{oo}) \pm \mathrm{SE}$ & $\mathbf{N}$ & $\Delta_{D i-F o}$ & $T(\mathrm{~K})^{\dagger}$ & $1 \sigma$ & $T\left({ }^{\circ} \mathrm{C}\right)^{\dagger}$ & $T(\mathrm{~K}) \ddagger$ & Data Source \\
\hline DaG 476 & $\mathrm{px}(D i)$ & $4.708 \pm 0.045$ & 2 & & & 105 & & & [63] \\
\hline $\mathrm{DaG} 476$ & ol $(F o)$ & $4.301 \pm 0.024$ & 3 & $0.407 \pm 0.05$ & 1470 & -90 & 1200 & 1480 & [63] \\
\hline SaU 008 & $\operatorname{px}(D i)$ & $4.533 \pm 0.045$ & 2 & & & 220 & & & [63] \\
\hline NWA 2046 & $\operatorname{px}(D i)$ & $4.62 \pm 0.09$ & 2 & & & 330 & & & [84] \\
\hline NWA 2046 & ol $(F o)$ & $4.27 \pm 0.17$ & 2 & $0.35 \pm 0.19$ & 1595 & -890 & 1320 & 1620 & [84] \\
\hline ALHA 77005 * & $\mathrm{px}(\mathrm{Di})$ & $4.72 \pm 0.07$ & 1 & & & 130 & & & [84] \\
\hline NWA 1950 * & ol $(F o)$ & $4.33 \pm 0.03$ & 6 & $0.29 \pm 0.06$ & 1765 & -230 & 1490 & 1780 & [84] \\
\hline
\end{tabular}
with the estimated temperature of SaU 008 are relatively larger than those of the DaG 476. There is a 230 degrees difference between the face values of the two meteorites despite the large uncertainties in temperature estimation and errors overlap by 30 degrees (Figure 3).

Table 1. Oxygen isotopic compositions of pyroxene and olivine in shergottites. Estimated temperatures are also listed.

DaG = Dar al Ghani. SaU = Sayh al Uhaymir. NWA = Northwest Africa. ALHA = Allan Hills, Antarctica. $\mathrm{SE}=$ Standard Error. $\mathrm{px}=$ pyroxene. $\mathrm{ol}=$ olivine. $\mathrm{Di}=$ diopside. Fo $=$ forsterite. $\mathrm{N}=$ number of individual runs. Oxygen isotope data taken from [63,84]. Errors in $\delta^{18} \mathrm{O}$ data of DaG 476 and SaU 008 represent the external reproducibility of several individual runs of San Carlos olivine (5.256 $\pm 0.045, \mathrm{~N}=5)$, except DaG 476 ol [63]. However, errors in $\delta^{18} \mathrm{O}$ data of other shergottites are taken from [81]. Additive propagated errors on $\Delta_{D i-F o}$ are calculated by taking the square root of the sum of the squares of uncertainty in $\delta^{18} \mathrm{O}$ values. ${ }^{+}$Calculated using Equation (5) derived from [80]. $\ddagger$ Calculated using Equation (6) derived from [81]. Samples marked with asterisk $\left({ }^{*}\right)$ are lherzolitic shergottites. 


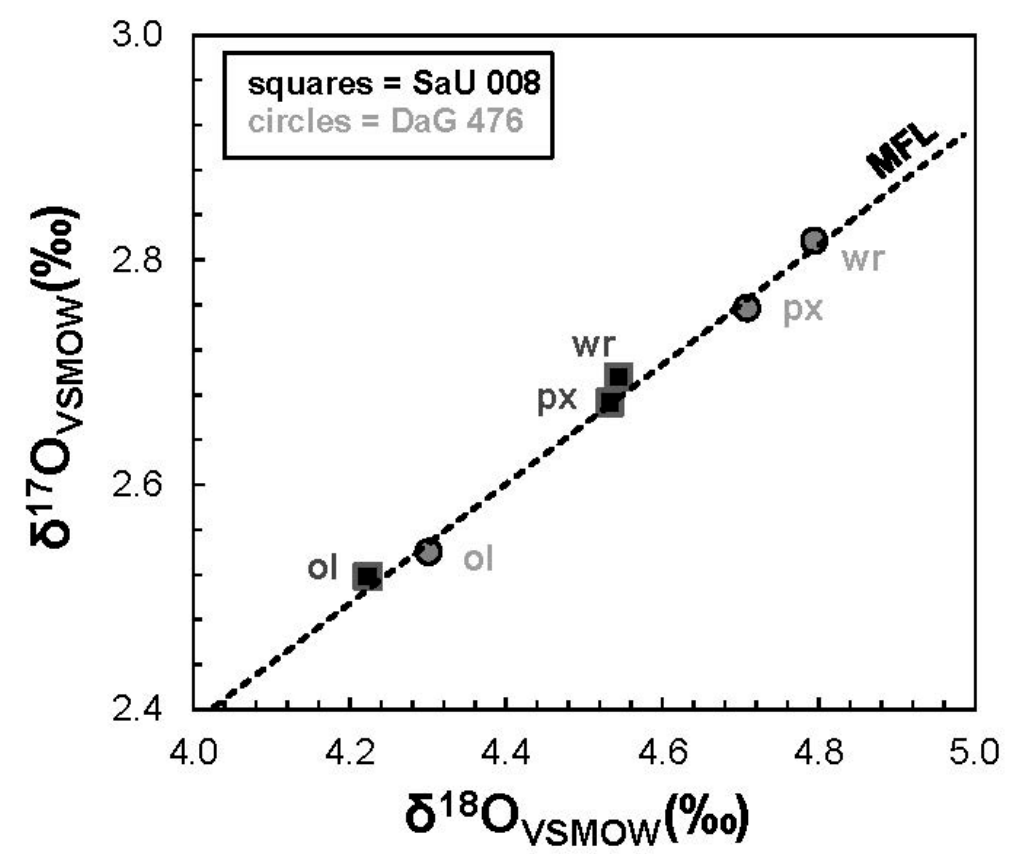

Figure 1. Three oxygen isotope plot of pyroxene (px), olivine (ol) separates, and whole rocks (wr) of DaG 476 and SaU 008 meteorites. MFL represents a line with a slope of $0.532 \pm 0.009$ (SE) [63]. This is the first MFL based on oxygen isotope data of minerals (px, ol) and maskelynite fractions of SNC (Shergotty-Nakhla-Chassigny) meteorites reported by [63].

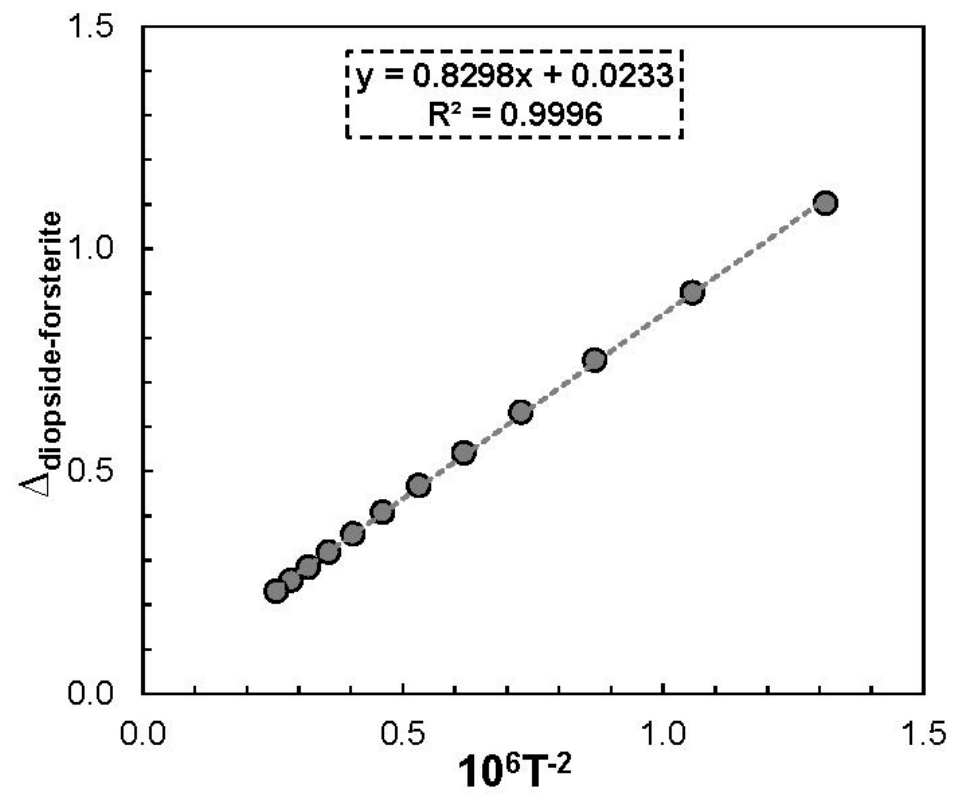

Figure 2. Plot showing linear relationship between inverse square of temperature $\left(10^{6} / T^{2}\right)$ and oxygen isotopic fractionation between diopside and forsterite $\left(\Delta_{D i-F o}\right)$ mineral pair. 


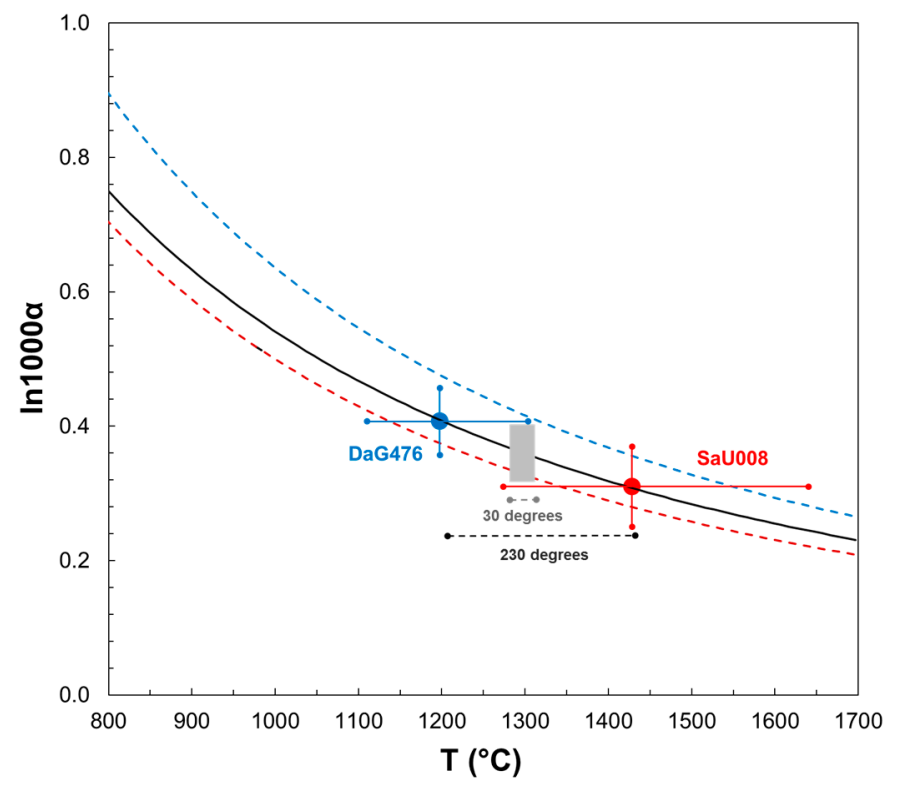

Figure 3. Plot of $T\left({ }^{\circ} \mathrm{C}\right)$ vs. $\ln 1000 \propto$ for DaG 476 and SaU 008 meteorites. Black line is based on the polynomial expressions (Equations (1) and (2); [80]). The temperatures of the meteorites are estimated from Equation (5) using linear parameters of the line shown in Figure 2. The red and blue dotted lines represent data calculated from Equation (6) [81] using coefficient factor values ranging from 0.81 to 1.03 (i.e., $A=0.92 \pm 0.11$ ) respectively.

\subsection{Petrogenetic Relationship}

The mantle melting zone shows temperature stratification (i.e., increase with increasing depth) that range from $\sim 1400{ }^{\circ} \mathrm{C}$ to $\sim 1700{ }^{\circ} \mathrm{C}$ [82]. Melt trapping in the olivine of $\mathrm{DaG} 476$ has been reported at $\sim 1275{ }^{\circ} \mathrm{C}$ followed by ascent and cooling that assisted crystallization of abiotic macromolecular carbon, spinel, and pyroxene in the melt inclusions of DaG 476 [82]. Our temperature estimation $\left(\sim 1200{ }^{\circ} \mathrm{C}\right)$ using pyroxene-olivine oxygen isotope thermometer for DaG 476 show a close resemblance. The oxygen fugacities of DaG 476 and SaU 005, estimated by olivine-pyroxene-spinel equilibria [47], are QFM -3.4 and QFM -2.5 , respectively, and correspond to relatively lower mean temperature for the former (i.e., $980{ }^{\circ} \mathrm{C}$; [47]) than that of the latter (i.e., $1086{ }^{\circ} \mathrm{C}$; [47]. Higher temperature $\left(1430{ }^{\circ} \mathrm{C}\right)$ estimated for $\mathrm{SaU} 008$ using diopside-forsterite oxygen isotope thermometry implies that the magma could have originated at higher pressure, potentially due to its deeper residence in the mantle (Figure 4). The systematically higher temperatures from px-ol oxygen isotope thermometry than those from the ol-px-sp equilibria may be due to the disequilibrium that existed between all 3 phases in the latter [47]. However, oxygen isotopic compositions of bulk materials and minerals of both meteorites are well in isotopic equilibrium (Figure 1), suggesting that estimated temperatures are robust. Higher olivine modal abundance in SaU 005 (22-31 vol \%; [6], Ni = 310 ppm; [85]) may support the idea that SaU 005 in comparison to DaG 476 (10-24 vol \%; [6], Ni = 240 ppm; [85]) had crystallized at deeper levels in the Martian interior. Furthermore, the range in SaU 005 olivine Mg\# (68 at core) [86] compared to that of other shergottites is restricted (est. 60-72; see Figure 3c in [87]). It is evident that olivine $\mathrm{Mg \#}$ is directly proportional to its $\mathrm{MgO}$ content that, in turn, is correlated with olivine crystallization temperatures $\left(1050-1525^{\circ} \mathrm{C}\right.$ ) observed in basalts (see Figure 1 in [88]). In addition, forsterite ( $\mathrm{Fo}$ ) contents and $\mathrm{Mg \#}$ values of olivines are often used interchangeably to assess the $\mathrm{MgO}$ content and are inversely related to their $\delta^{18} \mathrm{O}$ compositions as observed in olivine from $\mathrm{CI}$ chondrite, Orgueil [89]. The results of the fractional crystallization modeling by MELTS algorithm (i.e., a software for thermodynamic modeling of phase equilibria in magmatic systems) [15] using Y980459 as parent composition reveal that the change in temperature $\left(1170-1270{ }^{\circ} \mathrm{C}\right)$ during sequential crystallization of minerals (e.g., opx to pigeonite) from a liquid is associated with a proportional change 
in mean En content (e.g., pigeonite = 56, opx = 78; [15]). Mean En content in the pigeonite of DaG 489

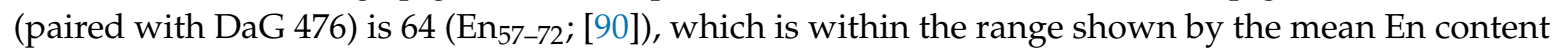
obtained from fractional crystallization model for the crystallization sequence of opx to pigeonite (i.e., 56-78; [15]). The temperature estimated for DaG 476 from oxygen isotope thermometry $\left(1200{ }^{\circ} \mathrm{C}\right)$ is consistent with the temperature range $\left(1170-1270{ }^{\circ} \mathrm{C}\right)$ obtained from MELTS fractional crystallization modelling [15]. The olivine-phyric shergottites represent a significant and important subgroup of Martian shergottites [65]. They contain cumulate olivines with relatively high core $\mathrm{Mg \#}$ values, which suggest that they could represent unfractionated liquids formed by the direct melting of the Martian mantle, namely, primitive melts [55]. Application of the oxygen isotope data of minerals formed from the primitive melts (i.e., px-ol) provides useful information regarding the temperature conditions of Mars' interior. However, the sensitivity of this thermometry to small analytical uncertainties in oxygen isotopic compositions of these minerals could produce large errors. For example, the temperatures calculated for other shergottites using their px-ol data [84] are associated with large errors (Table 1). Regardless of the errors, we will discuss our estimated temperatures at their face values that may likely be different given other contrasting chemical and isotopic signatures observed between the two meteorites.

The partial melting processes in the source regions of magmas are greatly influenced by the volatiles (e.g., water, halogens) that are partly lost upon eruption [56], making the estimation of water contents indigenous to the magma difficult. However, experimental studies suggest that $\sim 2 \mathrm{wt}$. \% water may be sought to reproduce the mineralogy and temperatures of crystallization of shergottites [57,91-93]. Furthermore, D/H isotope compositions of DaG 476 show negative correlation between $\delta \mathrm{D}$ (i.e., $352 \pm 18$ to $2347 \pm 85 \%$ ) and water abundance (relatively higher) in their feldspathic glasses (shocked plagioclase; e.g., maskelynite). The reverse is the case for SaU 005 (e.g., show positive correlation; $\delta \mathrm{D}=-105 \pm 17$ to $3257 \pm 41 \%$, low water) [94]. The contrasting trends in both meteorites suggest a mixing of a fractionated Martian water component having high $\delta \mathrm{D}(3000-4000 \%)$ with possibly a terrestrial component having low $\delta \mathrm{D}(\sim 0 \%)$ [94]. The difference in $\mathrm{D} / \mathrm{H}$ ratios between the two meteorites may possibly be related to the difference in the source regions of the two meteorites.

Recently, it has been observed that halogens (i.e., $\mathrm{Cl}$, F) have identical influence on crystallization temperatures of magmas similar to the effect of water [95-97]. Therefore, water and/or halogens may be required to reproduce the mineralogy of the shergottites. Given the uncertainty associated with estimation of indigenous water and halogen contents in the Martian magmas, it is rather useful to apply oxygen isotope thermometry using nominally anhydrous minerals. Olivine liquidus temperature (i.e., $1430{ }^{\circ} \mathrm{C}$ for Y980459) depends on melt composition and pressure [15]. The composition of the liquidus olivine is a function of melt composition, pressure, and temperature [98]. The fractional crystallization of mid-ocean ridge basalt (MORB) on terrestrial conditions is mainly affected by the water content in the magma. This is supposed to decrease the melt liquidus temperature and to suppress the plagioclase crystallization relative to olivine and clinopyroxene [99]. Experiments suggest that the parental magma of Y980459 could have been hydrous [100]. Furthermore, it is envisaged that water in the Martian mantle is heterogeneously distributed based on the estimates from the SNCs (i.e., 14-250 ppm; [46]. However, depleted shergottite mantle source is relatively water-poor (i.e., 14-23 ppm; [46]) compared to the enriched ones (i.e., 36-73 ppm; [46]). Mantle derived water that exhumed on the Martian surface in large fluxes during the earlier history of Mars (Noachian to early Hesperian periods; [23]), has been followed by further water contributions from shergottite-like magmatism during the Amazonian era [23].

Recently, pressure (i.e., $2.7 \mathrm{GPa}$ ) and temperature (i.e., $1600{ }^{\circ} \mathrm{C}$ ) of formation of NWA 6234, an olivine-phyric shergottite, were estimated from olivine-melt Mg-exchange thermometry [55]. They suggested that high pressure and temperature (i.e., PT) conditions indicate that NWA 6234 may have derived from a unique source region deeper in the Martian interior. Furthermore, NWA 6234 recorded that merrillite reacted with an $\mathrm{OH}-\mathrm{Cl}-\mathrm{F}-$ rich melt to form apatite [55]. Shergottites contain trace quantities of apatite that is relatively more abundant in the enriched ones compared to their 
depleted counterparts [46]. It has been observed that all phosphate grains present in SaU 094 and SaU 150 meteorites, paired with SaU 005/008, represent merrillite, and no apatite has been found $[69,101]$. However, petrographic observations revealed that both merrillite and apatite are present in DaG 476 [101]. Apatite observed in DaG 476 have patchy texture that is consistent with anhedral growth on the rims of other late-stage minerals, such as merrillite and pyroxene [46]. However, whether it is the product of igneous crystallization or formed later by fluid-rock interactions is not well known. The chlorine content in DaG 476 (840 ppm; [33]) is approximately six times larger than that of the SaU 005 (143 ppm; [72]). Most of the rock's chlorine budget comes from the mineral apatite. This suggests that the magmas in equilibrium with the apatite could have been enriched in chlorine. Moreover, high Na-contents (1.0-1.2 wt \%; [55]) in merrillite of DaG 476 demonstrate that merrillite crystallized earlier than plagioclase. These observations suggest that PT conditions could have been different for the formation of these meteorites and probably confirm that they could have been originated from source regions of the Martian mantle at different depths. Furthermore, DaG 476 may have encountered with $\mathrm{OH}-\mathrm{Cl}-\mathrm{F}-$ rich melt during its ascent, resulting in the reaction with merrillite to form apatite, something that SaU 008 did not experience.

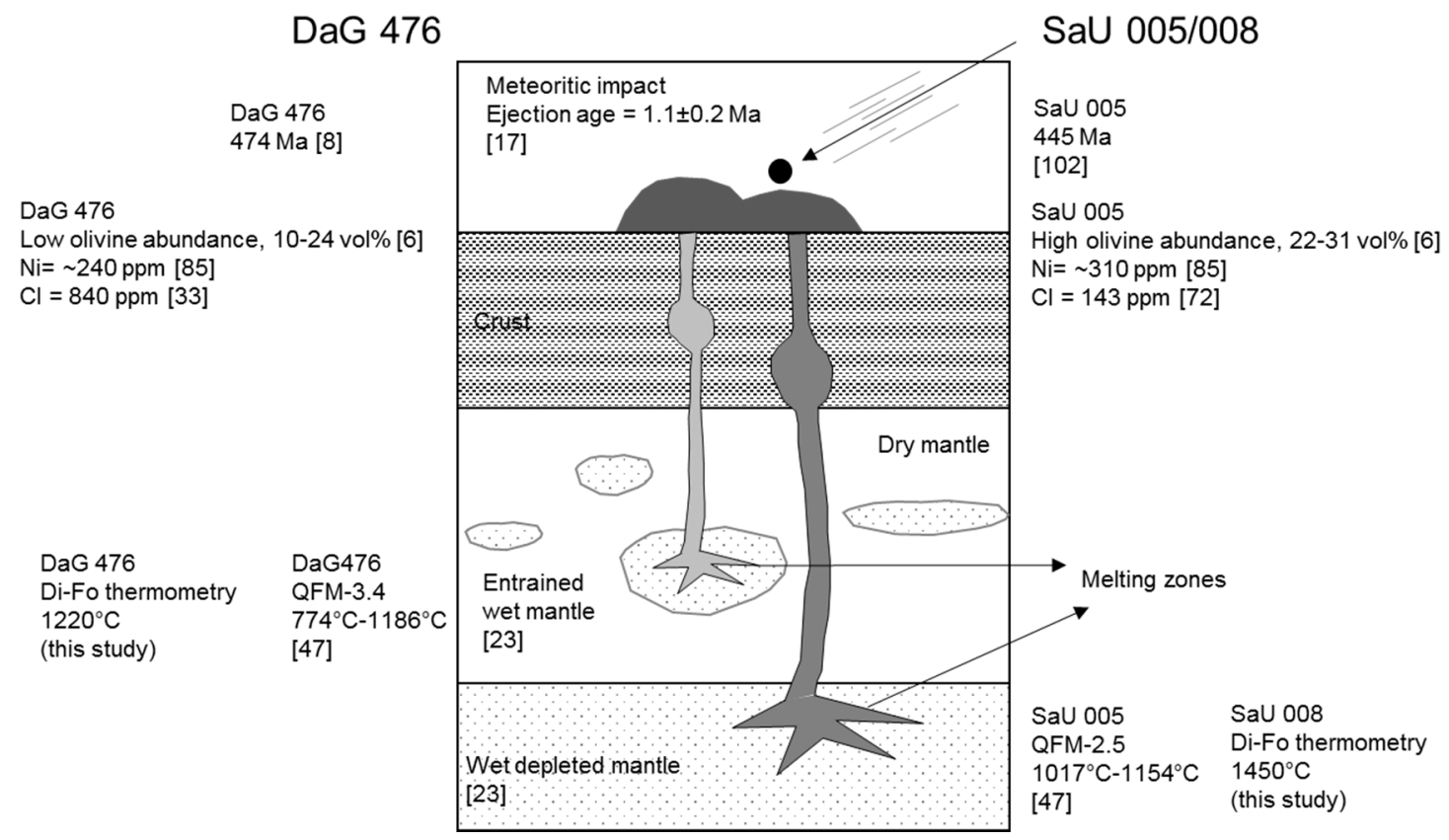

Figure 4. A simplified schematic diagram showing petrogenetic relationship between $\mathrm{DaG} 476$ and SaU 005/008, modified after $[15,23]$. The data of SaU 005 is used here for SaU 008, assuming that these meteorites are paired. Both DaG 476 (474 $\pm 11 \mathrm{Ma}$; [8]) and SaU 005 (445 $\pm 18 \mathrm{Ma}$; [102]) belong to Amazonian era when lower wet (depleted) and upper (degassed) dry (intermediate/enriched) mantle existed along with scattered pockets of hydrous materials in the upper dry mantle. Depth is not to scale.

\section{Conclusions}

Oxygen isotope fractionation between pyroxene and olivine minerals during crystallization in the magma chamber provide useful means to estimate the equilibration temperature. Oxygen isotope thermometry using pyroxene-olivine (proxy for diopside-forsterite) pair is applied to calculate the temperatures in two olivine-phyric shergottites (i.e., DaG 476 and SaU 008), showing that the two meteorites have $230{ }^{\circ} \mathrm{C}$ difference in their equilibration temperatures at the face values (i.e., $\left.\mathrm{SaU} 008=1430+220 /-155^{\circ} \mathrm{C} ; \mathrm{DaG} 476=1200+105 /-90{ }^{\circ} \mathrm{C}\right)$, even though the values are associated with large errors. To support the difference in our estimated temperatures, we investigated that both meteorites show contrasting geochemical and isotopic characteristics, such as (i) oxygen fugacities, (ii) olivine abundances, (iii) $\mathrm{D} / \mathrm{H}$ ratios, (iv) occurrence of merrillite/apatite minerals, and (v) chlorine 
contents. Earlier magmatic models have proposed that olivine-phyric shergottites were originated from a depleted and wet magma sources. Equilibration temperatures suggest that SaU 008 could have sourced the deeper depleted mantle reservoir whereas $\mathrm{DaG} 476$ was potentially produced by the partial melting in the entrained upwelling of the similar mantle at relatively shallower depth. We also propose that both meteorites erupted simultaneously as a relatively thick lava flow or a shallow intrusion followed by a launch initiated by a single meteoritic impact circa 1.1 Ma.

Acknowledgments: Authors are thankful to the guest editor, Elias Chatzitheodoridis for his helpful suggestions and professional editorial handling. This paper has been benefitted from the critical reviews of three anonymous reviewers. Funding for this work was provided by NSERC, the Ontario Centres of Excellence, CFI, and the UWO Academic Development Fund.

Author Contributions: Arshad Ali conceived the idea and discussed with co-authors. Sobhi Nasir focused on the petrogenetic part of this communication. Iffat Jabeen, Arshad Ali, and Neil Banerjee contributed in the analytical methods and data collection reported earlier. Arshad Ali and Sobhi Nasir performed the calculations. Arshad Ali and Iffat Jabeen wrote the paper.

Conflicts of Interest: The authors declare no conflict of interest.

\section{References}

1. Neukum, G.; Jaumann, R.; Hoffmann, H.; Hauber, E.; Head, J.W.; Basilevsky, A.T.; Ivanov, B.A.; Werner, S.C.; van Gasselt, S.; Murray, J.B.; et al. Recent and episodic volcanic and glacial activity on Mars revealed by the High Resolution Stereo Camera. Nature 2004, 432, 971-979. [CrossRef] [PubMed]

2. Van Thienen, P.; Rivoldini, A.; Van Hoolst, T.; Lognonné, P. A top-down origin for martian mantle plumes. Icarus 2006, 185, 197-210. [CrossRef]

3. Werner, S.C. The global martian volcanic evolutionary history. Icarus 2009, 201, 44-68. [CrossRef]

4. Robbins, S.J.; Di Achille, G.; Hynek, B.M. The volcanic history of Mars: High resolution crater-based studies of the calderas of 20 volcanoes. Icarus 2011, 211, 1179-1203. [CrossRef]

5. Bridges, J.C.; Warren, P.H. The SNC meteorites: Basaltic igneous processes on Mars. J. Geol. Soc. Lond. 2006, 163, 229-251. [CrossRef]

6. Liu, Y.; Baziotis, I.P.; Asimow, P.D.; Bodnar, R.J.; Taylor, L.A. Mineral chemistry of the Tissint meteorite: Indications of two-stage crystallization in a closed system. Meteorit. Planet. Sci. 2016, 51, 2293-2315. [CrossRef]

7. Borg, L.E.; Nyquist, L.E.; Wiesmann, H.; Shih, C.-Y. Constraints on martian differentiation processes from $\mathrm{Rb}-\mathrm{Sr}$ and Sm-Nd isotopic analyses of the basaltic shergottite QUE 94201. Geochim. Cosmochim. Acta 1997, 61, 4915-4931. [CrossRef]

8. Borg, L.E.; Draper, D.S. A petrogenetic model for the origin and compositional variation of the Martian basaltic meteorites. Meteorit. Planet. Sci. 2003, 38, 1713-1731. [CrossRef]

9. Borg, L.E.; Brennecka, G.A.; Symes, S.J.K. Accretion timescale and impact history of Mars deduced from the isotopic systematics of martian meteorites. Geochim. Cosmochim. Acta 2016, 175, 150-167. [CrossRef]

10. Borg, L.E.; Brennecka, G.A.; Marks, N.; Symes, S.J.K. Neodymium isotopic evolution of the solar system inferred from isochron studies of planetary materials. In Proceedings of the 44th Lunar Planetary Science Conference, The Woodlands, TX, USA, 18-22 March 2014.

11. Bouvier, A.; Blichert-Toft, J.; Vervoort, J.D.; Albarède, F. The age of SNC meteorites and the antiquity of the Martian surface. Earth Planet. Sci. Lett. 2005, 240, 221-233. [CrossRef]

12. Bouvier, A.; Blichert-Toft, J.; Vervoort, J.D.; Gillet, P.; Albarède, F. The case for old basaltic shergottites. Earth Planet. Sci. Lett. 2008, 266, 105-124. [CrossRef]

13. Nyquist, L.E.; Bogard, D.D.; Shih, C.-Y.; Greshake, A.; Stöffler, D.; Eugster, O. Ages and histories of martian meteorites. In Chronology and Evolution of Mars; Kallenbach, R., Geiss, J., Hartmann, W.K., Eds.; Springer: Berlin, Germany, 2001; pp. 105-164.

14. Shih, C.-Y.; Nyquist, L.E.; Wiesmann, H.; Reese, Y.; Misawa, K. Rb-Sr and Sm-Nd dating of olivine-phyric shergottites Y980459: Petrogenesis of depleted shergottites. Antarct. Meteorit. Res. 2005, 18, 46-65.

15. Symes, S.J.K.; Borg, L.E.; Shearer, C.K.; Irving, A.J. The age of the martian meteorite Northwest Africa 1195 and the differentiation history of the shergottites. Geochim. Cosmochim. Acta 2008, 72, 1696-1710. [CrossRef] 
16. Lapen, T.J.; Righter, M.; Brandon, A.D.; Debaille, V.; Beard, B.L.; Shafer, J.T.; Peslier, A.H. A young age for ALH84001 and its geochemical link to shergottite sources in Mars. Science 2010, 328, 347-351. [CrossRef] [PubMed]

17. Lapen, T.J.; Righter, M.; Andreasen, R.; Irving, A.J.; Satkoski, A.M.; Beard, B.L.; Nishiizumi, K.; Jull, A.J.T.; Caffee, M.W. Two billion years of magmatism recorded from a single Mars meteorite ejection site. Sci. Adv. 2017, 3, e1600922. [CrossRef] [PubMed]

18. Hartmann, W.K.; Berman, D.C. Elysium Planitia lava flows: Crater count chronology and geological implications. J. Geophys. Res. 2000, 105, 15011-15026. [CrossRef]

19. Stolper, E.; McSween, H.Y. Petrology and origin of the shergottite meteorites. Geochim. Cosmochim. Acta 1979, 43, 1475-1498. [CrossRef]

20. Herd, C.D.K.; Borg, L.E.; Jones, J.H.; Papike, J.J. Oxygen fugacity and geochemical variations in the martian basalts: Implications for martian basalt petrogenesis and the oxidation state of the upper mantle of Mars. Geochim. Cosmochim. Acta 2002, 66, 2025-2036. [CrossRef]

21. Wadhwa, M. Redox state of Mars' upper mantle and crust from Eu anomalies in shergottite pyroxenes. Science 2001, 291, 1527-1530. [CrossRef] [PubMed]

22. Brennecka, G.A.; Borg, L.E.; Wadhwa, M. Insights into the martian mantle: The age and isotopics of the meteorite fall Tissint. Meteorit. Planet. Sci. 2014, 49, 412-418. [CrossRef]

23. Balta, J.B.; McSween, H.Y. Water and the composition of Martian magmas. Geology 2013, 41, 1115-1118. [CrossRef]

24. Tornabene, L.L.; Moersch, J.E.; McSween, H.Y.; McEwen, A.S.; Piatek, J.L.; Milam, K.A.; Christensen, P.R. Identification of large $(2-10 \mathrm{~km}$ ) rayed craters on Mars in THEMIS thermal infrared images: Implications for possible Martian meteorite source regions. J. Geophys. Res. 2006, 111, E10006. [CrossRef]

25. Lang, N.P.; Tornabene, L.L.; McSween, H.Y.; Christensen, P.R. Tharsis-sourced relatively dust-free lavas and their possible relationship to martian meteorites. J. Volcanol. Geotherm. Res. 2009, 185, 103-115. [CrossRef]

26. French, B.M.; Short, N.M. (Eds.) Shock Metamorphism of Natural Materials; Mono Book Corporation: Baltimore, MD, USA, 1968.

27. Stöffler, D. Progressive metamorphism and classification of shocked and brecciated crystalline rocks at impact craters. J. Geophys. Res. 1971, 76, 5541-5551. [CrossRef]

28. Melosh, H.J. Impact Cratering: A Geologic Process; Oxford University Press: New York, NY, USA, 1989 ; p. 253.

29. Osinski, G.R.; Pierazzo, E. Impact Cratering: Processes and Products; Wiley-Blackwell: Oxford, UK, $2013 ;$ p. 316.

30. Jaret, S.J.; Woerner, W.R.; Phillips, B.L.; Ehm, L.; Nekvasil, H.; Wright, S.P.; Glotch, T.D. Maskelynite formation via solid-state transformation: Evidence of infrared and X-ray anisotropy. J. Geophys. Res. Planets 2015, 120, 570-587. [CrossRef]

31. Walton, E.L.; Herd, C.D.K. Localized shock melting in lherzolitic shergottite Northwest Africa 1950: Comparison with Allan Hills 77005. Meteorit. Planet. Sci. 2007, 42, 63-80. [CrossRef]

32. Chatzitheodoridis, E.; Haigh, S.; Lyon, I. A conspicuous clay ovoid in Nakhla: Evidence for subsurface hydrothermal alteration on Mars with implications for astrobiology. Astrobiology 2014, 14, 651-693. [CrossRef] [PubMed]

33. Zipfel, J.; Scherer, P.; Spettel, B.; Schultz, L. Petrology and chemistry of the new shergottite Dar al Gani 476. Meteorit. Planet. Sci. 2000, 35, 95-106. [CrossRef]

34. Fritz, J.; Artemieva, N.; Greshake, A. Ejection of Martian meteorites. Meteorit. Planet. Sci. 2005, 40, $1393-1411$. [CrossRef]

35. Pickersgill, A.E. Shock Metamorphic Effects in Lunar and Terrestrial Plagioclase Feldspar Investigated by Optical Petrography and Micro-X-ray Diffraction. Electronic Thesis and Dissertation Repository. Master's Thesis, University of Western Ontario, London, ON, Canada, 2014.

36. Ostertag, R. Shock experiments on feldspar crystals. J. Geophys. Res. 1983, 88, B364-B376. [CrossRef]

37. Kieffer, S.W. Numerical models of caldera-scale volcanic eruptions on Earth, Venus, and Mars. Science 1995, 269, 1385-1391. [CrossRef] [PubMed]

38. Glaze, L.S.; Baloga, S.M.; Wimert, J. Explosive volcanic eruptions from linear vents on Earth, Venus, and Mars: Comparisons with circular vent eruptions. J. Geophys. Res. 2011, 116. [CrossRef]

39. Usui, T.; McSween, H.Y., Jr.; Floss, C. Petrogenesis of olivine-phyric shergottite Yamato 980459, revisited. Geochim. Cosmochim. Acta 2008, 72, 1711-1730. [CrossRef] 
40. Blichert-Toft, J.; Gleason, J.D.; Télouk, P.; Albarède, F. The Lu-Hf isotope geochemistry of shergottites and the evolution of the Martian mantle-crust system. Earth Planet. Sci. Lett. 1999, 173, 25-39. [CrossRef]

41. Elkin-Tanton, L.T.; Parmentier, E.M.; Hess, P.C. Magma ocean fractional crystallization and cumulate overturn in terrestrial planets: Implications for Mars. Meteorit. Planet. Sci. 2003, 38, 1753-1771. [CrossRef]

42. Jones, J.H. Isotopic relationships among the shergottites, the nakhlites and Chassigny. In Proceedings of the 19th Lunar and Planetary Science Conference, Houston, TX, USA, 14-18 March 1988; pp. 465-474.

43. Leshin, L.A.; Epstein, S.; Stolper, E.M. Hydrogen isotope geochemistry of SNC meteorites. Geochim. Cosmochim. Acta 1996, 60, 2635-2650. [CrossRef]

44. Basu Sarbadhikari, A.; Babu, E.V.S.S.K.; Vijaya Kumar, T. Chemical layering in the upper mantle of Mars: Evidence from olivine-hosted melt inclusions in Tissint. Meteorit. Planet. Sci. 2016, 51, 251-267. [CrossRef]

45. Filiberto, J.; Gross, J.; McCubbin, F.M. Constraints on the water, chlorine, and fluorine content of the Martian mantle. Meteorit. Planet. Sci. 2016, 51, 2023-2035. [CrossRef]

46. McCubbin, F.M.; Boyce, J.W.; Srinivasan, P.; Santos, A.R.; Elardo, S.M.; Filiberto, J.; Steele, A.; Shearer, C.K. Heterogeneous distribution of $\mathrm{H}_{2} \mathrm{O}$ in the Martian interior: Implications for the abundances of $\mathrm{H}_{2} \mathrm{O}$ in depleted and enriched mantle sources. Meteorit. Planet. Sci. 2016, 51, 2036-2060. [CrossRef]

47. Herd, C.D.K. The oxygen fugacity of olivine-phyric martian basalts and the components within the mantle and crust of Mars. Meteorit. Planet. Sci. 2003, 38, 1793-1805. [CrossRef]

48. Watson, L.L.; Hutcheon, I.D.; Epstein, S.; Stolper, E.M. Water on Mars: Clues from deuterium/hydrogen and water contents of hydrous phases in SNC meteorites. Science 1994, 265, 86-90. [CrossRef] [PubMed]

49. Leshin, L.A. Insights into martian water reservoirs from analyses of Martian meteorite QUE94201. Geophys. Res. Lett. 2000, 27, 2017-2020. [CrossRef]

50. Greenwood, J.P.; Itoh, S.; Sakamoto, N.; Vicenzi, E.P.; Yurimoto, H. Hydrogen isotope evidence for loss of water from mars through time. Geophys. Res. Lett. 2008, 35. [CrossRef]

51. McCubbin, F.M.; Smirnov, A.; Nekvasil, H.; Wang, J.; Hauri, E.; Lindsley, D.H. Hydrous magmatism on Mars: A source of water for the surface and subsurface during the Amazonian. Earth Planet. Sci. Lett. 2010, 292, 132-138. [CrossRef]

52. McCubbin, F.M.; Hauri, E.; Elardo, S.M.; Vander Kaaden, K.E.; Wang, J.; Shearer, C.K. Hydrous melting of the Martian mantle produced both depleted and enriched shergottites. Geology 2012, 40, 683-686. [CrossRef]

53. Usui, T.; Alexander, C.M.O.D.; Wang, J.; Simon, J.I.; Jones, J.H. Origin of water and mantle-crust interactions on Mars inferred from hydrogen isotopes and volatile element abundances of olivine-hosted melt inclusions of primitive shergottites. Earth Planet. Sci. Lett. 2012, 357-358, 119-129. [CrossRef]

54. Usui, T.; Alexander, C.M.O.D.; Wang, J.; Simon, J.I.; Jones, J.H. Meteoritic evidence for a previously unrecognized hydrogen reservoir on Mars. Earth Planet. Sci. Lett. 2015, 410, 140-151. [CrossRef]

55. Gross, J.; Filiberto, J.; Herd, C.D.K.; Melwani Daswani, M.; Schwenzer, S.P.; Treiman, A.H. Petrography, mineral chemistry, and crystallization history of olivine-phyric shergottite NWA 6234: A new melt composition. Meteorit. Planet. Sci. 2013, 48, 854-871. [CrossRef]

56. McSween, H.Y.; Harvey, R.P. Outgassed water on Mars: Constraints from melt inclusions in SNC meteorites. Science 1993, 259, 1890-1892. [CrossRef] [PubMed]

57. Giesting, P.A.; Schwenzer, S.P.; Filiberto, J.; Starkey, N.A.; Franchi, I.A.; Trieman, A.H.; Tindle, A.G.; Grady, M.M. Igneous and shock processes affecting chassignite amphibole evaluated using chlorine/water partitioning and hydrogen isotopes. Meteorit. Planet. Sci. 2015, 50, 433-460. [CrossRef]

58. Dann, J.C.; Holzheid, A.H.; Grove, T.L.; McSween, H.Y., Jr. Phase equilibria of the Shergotty meteorite: Constraints on pre-eruptive water contents of martian magmas and fractional crystallization under hydrous conditions. Meteorit. Planet. Sci. 2001, 36, 793-806. [CrossRef]

59. Clayton, R.N.; Epstein, S. The use of oxygen isotopes in high temperature geological thermometry. J. Geol. 1961, 69, 447-452. [CrossRef]

60. Onuma, N.; Clayton, R.N.; Mayeda, T.K. Apollo 11 rocks: Oxygen isotope fractionation between minerals and an estimate of the temperature of formation. Geochim. Cosmochim. Acta 1970, 1, 1429-1434.

61. Clayton, R.N.; Onuma, N.; Mayeda, T.K. Oxygen isotope fractionation in Apollo 12 rocks and soils. In Proceedings of the 2nd Lunar and Planetary Science Conference, Houston, TX, USA, 11-14 January 1971; MIT Press: Cambridge, MA, USA; pp. 1417-1420.

62. Clayton, R.N. Oxygen isotope composition of Luna 16 soil. Earth Planet. Sci. Lett. 1972, 13, 455-456. [CrossRef] 
63. Ali, A.; Jabeen, I.; Gregory, D.; Verish, R.; Banerjee, N.R. New triple oxygen isotope data of bulk and separated fractions from SNC meteorites: Evidence for mantle homogeneity of Mars. Meteorit. Planet. Sci. 2016, 51, 981-995. [CrossRef]

64. Clayton, R.N.; Mayeda, T.K. Oxygen isotopes in Shergotty. Geochim. Cosmochim. Acta 1986, 50, 979-982. [CrossRef]

65. Goodrich, C.A. Olivine-phyric martian basalts: A new type of shergottite. Meteorit. Planet. Sci. 2002, 37, S12. [CrossRef]

66. Ali, A.; Nasir, S.; Jabeen, I.; Al Rawas, A. Review of the Sayh al Uhaymir (SaU) 005, plus pairings, Martian meteorite from Al Wusta, Oman. Sult. Qaboos Univ. J. Sci. 2017, 22, 29-39. [CrossRef]

67. Folco, L.; Franchi, I.A.; D'Orazio, M.; Rocchi, S.; Schultz, L. A new martian meteorite from the Sahara: The shergottite Dar al Gani 489. Meteorit. Planet. Sci. 2000, 35, 827-839. [CrossRef]

68. Wadhwa, M.; Lentz, R.C.F.; McSween, H.Y.; Crozaz, G. A petrologic and trace element study of Dar al Gani 476 and Dar al Gani 489: Twin meteorites with affinities to basaltic and lherzolitic shergottites. Meteorit. Planet. Sci. 2001, 36, 195-208. [CrossRef]

69. Walton, E.L.; Spray, J.G.; Bartoschewitz, R. A new Martian meteorite from Oman: Mineralogy, petrology, and shock metamorphism of olivine-phyric basaltic shergottite Sayh al Uhaymir 150. Meteorit. Planet. Sci. 2005, 40, 1195-1214. [CrossRef]

70. Crozaz, G.; Wadhwa, M. The terrestrial alteration of Saharan shergottites Dar al Gani 476 and 489: A case study of weathering in a hot desert environment. Geochim. Cosmochim. Acta 2001, 65, 971-978. [CrossRef]

71. Nishiizumi, K.; Caffee, M.W.; Jull, A.J.T.; Klandrud, S.E. Exposure history of Shergottites Dar al Gani 476/489/670/735 and Sayh al Uhaymir 005. In Proceedings of the 32nd Lunar and Planetary Science Conference, Houston, TX, USA, 12-16 March 2001.

72. Dreibus, G.; Spettel, B.; Haubold, R.; Jochum, K.P.; Palme, H.; Zipfel, J. Chemistry of a new shergottite: Sayh al Uhaymir 005. Meteorit. Planet. Sci. 2000, 35, A49.

73. Barrat, J.A.; Blichert-Toft, J.; Nesbitt, R.W.; Keller, F. Bulk chemistry of Saharan shergottite Dar al Gani 476. Meteorit. Planet. Sci. 2001, 34, 91-97. [CrossRef]

74. Crozaz, G.; Floss, C.; Wadhwa, M. Chemical alteration and REE mobilization in meteorites from hot and cold deserts. Geochim. Cosmochim. Acta 2003, 67, 4727-4741. [CrossRef]

75. Baertchi, P. Absolute $18 \mathrm{O}$ content of standard mean ocean water. Earth Planet. Sci. Lett. 1976, 31, 341-344. [CrossRef]

76. Quinn, R.J.; Kitajima, K.; Nakashima, D.; Spicuzza, M.J.; Valley, J.W. Oxygen isotope thermometry using quartz inclusions in garnet. J. Metamorph. Geol. 2017, 35, 231-252. [CrossRef]

77. Eiler, J.M.; Baumgartner, L.P.; Valley, J.W. Intercrystalline stable isotope diffusion-A fast grain-boundary model. Contrib. Mineral. Petrol. 1992, 112, 543-557. [CrossRef]

78. Eiler, J.M.; Baumgartner, L.P.; Valley, J.W. Fast grain-boundary-A Fortran-77 program for calculating the effects of retrograde interdiffuion of stable isotopes. Comput. Geosci. 1994, 20, 1415-1434. [CrossRef]

79. Dodson, M.H. Closure temperature in cooling geochronological and petrological systems. Contrib. Mineral. Petrol. 1973, 40, 259-274. [CrossRef]

80. Clayton, R.N.; Kieffer, S.W. Oxygen isotopic thermometer calibrations. In Stable Isotope Geochemistry: A Tribute to Samuel Epstein; Special Publication No. 3; Taylor, H.P., O’Neil, J.R., Kaplan, I.R., Eds.; The Geochemical Society: Washington, DC, USA, 1991; pp. 3-10.

81. Chiba, H.; Chacko, T.; Clayton, R.N.; Goldsmith, J.R. Oxygen isotope fractionations involving diopside, forsterite, magnetite, and calcite: Application to geothermometry. Geochim. Cosmochim. Acta 1989, 53, 2985-2995. [CrossRef]

82. Steele, A.; McCubbin, F.M.; Fries, M.; Kater, L.; Boctor, N.Z.; Fogel, M.L.; Conrad, P.G.; Glamoclija, M.; Spencer, M.; Morrow, A.L.; et al. A reduced organic carbon component in Martian basalts. Science 2012, 337, 212-215. [CrossRef] [PubMed]

83. Zheng, Y.-F. Prediction of high-temperature oxygen isotope fractionation factors between mantle minerals. Phys. Chem. Miner. 1997, 24, 356-364. [CrossRef]

84. Channon, M.B.; Stolper, E.M.; Eiler, J.M. Oxygen isotope compositions of mineral separates from SNC meteorites: Constraints on SNC parental magmas. In Proceedings of the 41st Lunar and Planetary Science Conference, Houston, TX, USA, 13-17 March 2010. 
85. Treiman, A.H.; Filiberto, J. Geochemical diversity of shergottite basalts: Mixing and fractionation, and their relation to mars surface basalts. Meteorit. Planet. Sci. 2015, 50, 632-648. [CrossRef]

86. Goodrich, C.A. Petrogenesis of olivine-phyric shergottites Sayh al Uhaymir 005 and Elephant Moraine A79001 lithology A. Geochim. Cosmochim. Acta 2003, 67, 3735-3771. [CrossRef]

87. Balta, J.B.; Sanborn, M.E.; Udry, A.; Wadhwa, M.; McSween, H.Y. Petrology and trace element geochemistry of Tissint, the newest shergottite fall. Meteorit. Planet. Sci. 2015, 50, 63-85. [CrossRef]

88. French, W.J.; Cameron, E.P. Calculation of the temperature of crystallization of silicates from basaltic melts. Mineral. Mag. 1981, 44, 19-26. [CrossRef]

89. Leshin, L.A.; Rubin, A.E.; McKeegan, K.D. The oxygen isotopic composition of olivine and pyroxene from CI chondrites. Geochim. Cosmochim. Acta 1997, 61, 835-845. [CrossRef]

90. Grossman, J.N. The Meteoritical Bulletin, No. 83, 1999 July. Meteorit. Planet. Sci. 1999, 34, 169-186. [CrossRef]

91. Nekvasil, H.; Filiberto, J.; McCubbin, F.M.; Lindsley, D.H. Alkalic parental magmas for the chassignites? Meteorit. Planet. Sci. 2007, 42, 979-992. [CrossRef]

92. Nekvasil, H.; McCubbin, F.M.; Harrington, A.D.; Elardo, S.M.; Lindsley, D.H. Linking the Chassigny meteorite and the Martian surface rock Backstay: Insights into igneous crustal differentiation processes on Mars. Meteorit. Planet. Sci. 2009, 44, 853-869. [CrossRef]

93. Filiberto, J. Experimental constraints on the parental liquid of the Chassigny meteorite: A possible link between the Chassigny meteorite and a Gusev basalt. Geochim. Cosmochim. Acta 2008, 72, 690-701. [CrossRef]

94. Boctor, N.Z.; Alexander, C.M.O.D.; Wang, J.; Hauri, E. The sources of water in Martian meteorites: Clues from hydrogen isotopes. Geochim. Cosmochim. Acta 2003, 67, 3971-3989. [CrossRef]

95. Filiberto, J.; Wood, J.; Dasgupta, R.; Shimizu, N.; Le, L.; Treiman, A.H. Effect of fluorine on near-liquidus phase equilibria of an Fe-Mg rich basalt. Chem. Geol. 2012, 312-313, 118-126. [CrossRef]

96. Filiberto, J.; Dasgupta, R.; Gross, J.; Treiman, A.H. Effect of chlorine on near-liquidus phase equilibria of a Fe-Mg-rich tholeiitic basalt. Contrib. Mineral. Petrol. 2014, 168, 1-13. [CrossRef]

97. Giehl, C.; Marks, M.W.; Nowak, M. An experimental study on the influence of fluorine and chlorine on phase relations in peralkaline phonolitic melts. Contrib. Mineral. Petrol. 2014, 167, 977. [CrossRef]

98. Ford, C.E.; Russell, D.G.; Craven, J.A.; Fisk, M.R. Olivine-liquid equilibria: Temperature, pressure, and composition dependence of the crystal/liquid cation partition coefficients for $\mathrm{Mg}, \mathrm{Fe}^{2+}, \mathrm{Ca}$ and $\mathrm{Mn}$. J. Petrol. 1983, 24, 256-265. [CrossRef]

99. Falloon, T.J.; Danyushevsky, L.V.; Arsikin, A.; Green, D.H.; Ford, C.E. The application of olivine geothermometry to infer crystallization temperatures of parental liquids: Implications for the temperature of MORB magmas. Chem. Geol. 2007, 241, 207-233. [CrossRef]

100. Draper, D.S. Water-undersaturated near-liquidus phase relations of Yamato 980459: Preliminary results. In Proceedings of the 38th Lunar and Planetary Science Conference, League City, TX, USA, 12-16 March 2007.

101. Gnos, E.; Hofmann, B.; Franchi, I.A.; Al-Kathiri, A.; Hauser, M.; Moser, L. Say al Uhaymir 094: A new martian meteorite from the Oman desert. Meteorit. Planet. Sci. 2002, 37, 835-854. [CrossRef]

102. Shih, C.; Nyquist, L.E.; Reese, Y. Rb-Sr and Sm-Nd isotopic studies of martian depleted shergottites SaU 094/005. In Proceedings of the 38th Lunar and Planetary Science Conference, League City, TX, USA, 12-16 March 2007.

(C) 2018 by the authors. Licensee MDPI, Basel, Switzerland. This article is an open access article distributed under the terms and conditions of the Creative Commons Attribution (CC BY) license (http:/ / creativecommons.org/licenses/by/4.0/). 